\title{
Prediction, prevention, and mechanism of early (anaphylactic) antivenom reactions in victims of snake bites
}

\author{
PRIDA MALASIT, DAVID A WARRELL, PORNTHEP CHANTHAVANICH, \\ CHAISIN VIRAVAN, JUTHATHIP MONGKOLSAPAYA, BENJAWAN SINGHTHONG, \\ CHALIDA SUPICH
}

\begin{abstract}
Victims of snake bites are often subjected to cutaneous or conjunctival hypersensitivity testing before being given antivenom. None of 12 early (anaphylactic) reactions was predicted by these tests in 25 Nigerian and Thai patients. The incidence and severity of early reactions was the same whether antivenom was given by intravenous injection over 10 minutes or diluted and given as an intravenous infusion over 30 minutes. Although antivenom activated complement in vitro, there was no evidence of complement activation or formation of immune complexes in patients bitten by snakes who were treated with antivenom, whether or not they developed early reactions. Higher doses of antivenom might induce the complement activation and formation of immune complexes (aggregates) that have been observed during the clinically more severe reactions associated with homologous immunoglobulin treatment.
\end{abstract}

\footnotetext{
Department of Medicine, Siriraj Hospital, Mahidol University, Bangkok, Thailand

PRIDA MALASIT, MD, MRCP, consultant renal physician JUTHATHIP MONGKOLSAPAYA, BSC, research fellow BENJAWAN SINGHTHONG, BSC, research fellow

Hospital for Tropical Diseases, Faculty of Tropical Medicine, Mahidol University, Bangkok 10400, Thailand

D A WARRELL, DM, FRCP, consultant

PORNTHEP CHANTHAVANICH, MD, DTM\&H, lecturer

CHAISIN VIRAVAN, MD, DTM\&H, associate professor

Science Division, Thai Red Cross Society, Queen Saovabha Memorial Institute, Bangkok, Thailand

CHALIDA SUPICH, MD, assistant director

Correspondence to: Dr Warrell.
}

\section{Introduction}

Antivenom, the serum of animals immunised with venom, is the only specific treatment for poisoning with snake venom. It is most effective by intravenous injection, ${ }^{12}$ but some patients quickly develop cutaneous or systemic anaphylaxis when it is given in this way. The incidence and severity of these early reactions is proportional to the dose of antivenom and the speed with which it enters the blood stream. ${ }^{3}$ The reported incidence of early reactions after intravenous antivenom ranges from $3 \%$ to $54 \%^{4.8}$; this depends partly on the quality of clinical observation during the critical one to two hours after treatment.

In most cases symptoms are mild: urticaria, nausea, vomiting, diarrhoea, headache, and fever; but in up to $40 \%$ of cases severe systemic anaphylaxis develops with bronchospasm, hypotension, or angioneurotic oedema. Surprisingly few deaths have been reported, ${ }^{5-10}$ but some anaphylactic deaths may have been wrongly attributed to envenoming. Mortality of anaphylaxis from other antisera was reported as $0 \cdot 1 \% .^{11}$ In England the death of an asthmatic boy from anaphylaxis induced by antivenom in 1957 led to the rejection of antivenom treatment on the grounds that the bite was less dangerous than the treatment. ${ }^{10} 1213$

Skin or conjunctival sensitivity tests have proved unreliable in predicting early reactions to antivenom ${ }^{414}$ is and reactions to other equine antisera, ${ }^{16}{ }^{17}$ but advocates are still found. ${ }^{14}{ }^{18-20}$ There have been no published reports of the value of sensitivity tests for antivenom treatment based on prospective studies. Early reactions were previously regarded as type I immediate hypersensitivity reactions to equine serum proteins, but their prevalence in populations never exposed to horses ${ }^{7}$ and the absence of specific cutaneous hypersensitivity in most reactive patients have prompted a search for other mechanisms. Sutherland found that eight out of nine commercial antivenoms were anticomplementary in vitro. ${ }^{21}$ These results led him and others to recommend slow intravenous infusion of diluted antivenom to reduce complement activation. ${ }^{815}$ This method, however, requires more equipment and supervision than the intravenous ("push") injection that is widely used in tropical countries, and its benefits have not been proved. We studied some of these problems of antivenom treatment in patients bitten by snakes. 


\section{Patients and methods}

In Bambur General Hospital and Ahmadu Bello University and Wusasa Hospitals, Zaria, northern Nigeria, we studied 15 patients with systemic envenoming by the saw-scaled or carpet viper (Echis carinatus). In Queen Saovabha Memorial Institute (Thai Red Cross Society), Bangkok and Trang Provincial Hospital and Pra Pokklao Provincial Hospital, Chantaburi, Thailand, we studied 19 patients with local or systemic envenoming by green pit vipers (Trimeresurus albolabris and $T$ macrops), two patients with local envenoming by the monocellate Thai cobra (Naja kaouthia), and 59 patients with systemic envenoming by the Malayan pit viper (Calloselasma rhodostoma). Patients gave written informed consent to take part in the study, which had been passed by local ethical committees.

\section{SENSITIVITY TESTS}

In Nigeria liquid antivenoms (Bitis-Echis-Naja polyspecific antivenom, Behringwerke, West Germany, and Echis monospecific antivenom, Institut Pasteur, Paris) were diluted 1 in 10 in isotonic saline: $0.02 \mathrm{ml}$ was given intradermally into the left forearm of 15 patients, ${ }^{14}$ and one drop was instilled

\section{IMMUNOLOGICAL STUDIES}

Blood samples were taken from 28 Thai patients with local or systemic envenoming from green pit vipers, Malayan pit vipers, or cobras before sensitivity tests were performed; immediately before the start of antivenom treatment; five, 15,30 , and 120 minutes later; and at the first sign of an early reaction. Plasma containing $0.1 \mathrm{mmol} / 1(3 \mathrm{mg} / 100 \mathrm{ml})$ edetic acid and serum were collected and stored at $-70^{\circ} \mathrm{C}$ until used. Serum samples were assayed for immune complexes by three methods: iodine- 125 protein $\mathrm{A}$ assay, ${ }^{23} \mathrm{Clq}$ binding ${ }^{24}$ and solid phase conglutinin ${ }^{25}$ with ${ }^{125} \mathrm{I}$ protein $\mathrm{A}$ instead of ${ }^{125} \mathrm{I}$ antiIgG to detect bound immune complexes. Protein A, purchased from the Public Health Laboratory Service, Porton Down, Wiltshire, was labelled with ${ }^{125} \mathrm{I}$ by the iodogen method (Pierce Chemical Company). ${ }^{26}$ For each analysis results that were more than two standard deviations away from values from a group of 25 healthy controls were regarded as positive.

Complement components and breakdown products were measured in samples of plasma containing $0.1 \mathrm{mmol} / 1$ edetic acid. $\mathrm{C} 3$ and $\mathrm{C} 4$ were measured by radial immunodiffusion with monospecific antisera. C3 breakdown products were detected with two dimensional immunoelectrophoresis with specific antisera against $\mathrm{C} 3$ and $\mathrm{C} 3 \mathrm{~b} .{ }^{27}$ Breakdown products were expressed as a percentage of the total amount of $\mathrm{C} 3$.

TABLE I-Results of sensitivity tests in 25 patients bitten by snakes

\begin{tabular}{|c|c|c|c|c|c|c|c|c|c|c|}
\hline \multirow[b]{2}{*}{$\begin{array}{c}\text { No } \\
\text { of } \\
\text { patients }\end{array}$} & \multirow[b]{2}{*}{ Country } & \multirow[b]{2}{*}{$\begin{array}{l}\text { Biting species of } \\
\text { snake }\end{array}$} & \multirow[b]{2}{*}{$\begin{array}{c}\text { Severity of } \\
\text { envenoming } \\
\text { (No of patients) }\end{array}$} & \multirow[b]{2}{*}{$\begin{array}{c}\text { Administration route } \\
\text { of } \\
\text { antivenom }\end{array}$} & \multirow[b]{2}{*}{$\begin{array}{c}\text { Dose } \\
\text { of } \\
\text { antivenom } \\
\text { (ampoules) }\end{array}$} & \multicolumn{2}{|c|}{ Positive results } & \multicolumn{3}{|c|}{ Negative results } \\
\hline & & & & & & $\begin{array}{c}\text { No } \\
\text { of } \\
\text { patients }\end{array}$ & $\begin{array}{l}\text { No of } \\
\text { reactions to } \\
\text { treatment }\end{array}$ & $\begin{array}{c}\text { No } \\
\text { of } \\
\text { patients }\end{array}$ & $\begin{array}{l}\text { No of } \\
\text { reactions to } \\
\text { treatment }\end{array}$ & $\begin{array}{c}\text { No of } \\
\text { severe } \\
\text { reactions }\end{array}$ \\
\hline 15 & Nigeria & Echis carinatus & Systemic & $\left\{\begin{array}{l}\text { Corneal } \\
\text { Intradermally } 0.02 \mathrm{ml}\end{array}\right.$ & $2 \mathrm{P}$ or $6 \mathrm{~B}$ & 1 & 0 & 14 & 3 & 1 \\
\hline & & & & ( 1 in 10 dilution $)$ & & 0 & 0 & 15 & 3 & 1 \\
\hline 20 & Thailand & $\left\{\begin{array}{l}\text { Trimeresurus albolabris } \\
\text { T macrops } \\
\text { Calloselasma rhodostoma } \\
\text { Naja kaouthia }\end{array}\right.$ & $\begin{array}{l}\text { Local }(12) \\
\text { Systemic (3) } \\
\text { Systemic (4) } \\
\text { Local }(1)\end{array}$ & Subcutaneously $0.2 \mathrm{ml}$ (neat) & $\begin{array}{l}1 \mathrm{TRC} \\
5 \mathrm{TRC}\end{array}$ & 1 & 0 & 19 & 9 & 1 \\
\hline
\end{tabular}

$\mathrm{P}=$ Institut Pasteur Echis carinatus monospecific antivenom; $\mathrm{B}=$ Behringwerke Bitis-Echis-Naja polyspecific antivenom; TRC $=$ Thai Red Cross monospecific antivenom.

into the left conjunctival sac. Plain isotonic saline $(0.02 \mathrm{ml})$ was injected intradermally into the right arm and one drop of saline instilled into the right conjunctival sac as controls.

In Thailand one ampoule of lyophilised antivenom (freeze dried green pit viper monospecific and Malayan pit viper monospecific antivenoms, Thai Red Cross, Thailand) was reconstituted with $10 \mathrm{ml}$ of sterile water and $0.2 \mathrm{ml}$ of this solution injected subcutaneously into the left forearm of 20 patients. ${ }^{22}$ Plain isotonic saline $(0.2 \mathrm{ml})$ was injected subcutaneously into the opposite arm as a control.

The patients were observed closely for 30 minutes after injection and instillation. The diameter of swelling and erythema on test and control forearms was then measured. Redness and itching were recorded in the patients in whom conjunctival tests had been performed. In every case the antivenom used for sensitivity testing was the same as that given subsequently for treatment of envenoming. All antivenoms were of equine origin.

\section{COMPARISON OF INTRAVENOUS INJECTION AND INFUSION OF ANTIVENOM}

Sixty six Thai patients with local or systemic envenoming by green pit vipers, Malayan pit vipers, or cobras were randomly allocated into two groups for treatment with either infusion or injection. Nineteen patients with bites from green pit vipers were given one or five vials of Thai Red Cross freeze dried monospecific antivenom and 48 patients with bites from Malayan pit vipers were given five vials of Thai Red Cross freeze dried (equine), Thai Government Pharmaceutical Organisation freeze dried (equine), or Twyford Pharmaceuticals liquid monospecific (caprine) antivenoms. Freeze dried antivenoms were dissolved in water ( $10 \mathrm{ml} / \mathrm{ampoule})$ and were either injected intravenously, without further dilution, over 10 minutes exactly or added to $200 \mathrm{ml}$ of isotonic saline and infused intravenously over 30 minutes.

Patients were observed closely for at least six hours after antivenom treatment. The timing and severity of early reactions were recorded. At the first sign of a reaction $0.5 \mathrm{ml}$ of $0.1 \%$ adrenaline was injected subcutaneously followed by $10 \mathrm{mg}$ of chlorpheniramine maleate by slow intravenous injection.
C3d was detected by double decker immunoelectrophoresis with a monospecific antiserum against C3d (Dakopatts, Denmark). Results were expressed as a percentage of $\mathrm{C} 3 \mathrm{~d}$ in an aged plasma pool. ${ }^{28}$

\section{ASSESSMENT OF IN VITRO COMPLEMENT ACTIVATION BY ANTIVENOM}

Lyophilised green pit viper antivenom (Thai Red Cross) was reconstituted with sterile water. Increasing amounts $(2-25 \mu \mathrm{l})$ were added to $25 \mu \mathrm{l}$ of normal human serum and incubated at $37^{\circ} \mathrm{C}$ for 30 minutes. The mixture was assayed for complement breakdown products by crossed immunoelectrophoresis. In a second experiment reconstituted antivenom was spun at $10000 \mathrm{~g}$ for 30 minutes to remove aggregates. Controls consisted of additions of edetic acid at a final concentration of $10 \mathrm{mmol} / \mathrm{l}(292 \mathrm{mg} / 100 \mathrm{ml})$ (to inhibit the classical and alternative pathways of complement activation) and ethyleneglycol tetra-acetic acid and magnesium chloride at final concentrations of 10 and $7 \mathrm{mmol} / 1$ ( 380 and $142 \mathrm{mg} / 100 \mathrm{ml}$ ), respectively (to inhibit the classical pathway of complement activation); normal serum alone; and reconstituted antivenom alone.

\section{STATISTICAL METHODS}

Fisher's exact test, $\chi^{2}$ test, and two tailed $t$ test were used for statistical analyses.

\section{Results}

\section{SENSITIVITY TESTS}

Table I gives the results of sensitivity tests in 25 patients bitten by snakes. None of the 12 early reactions (two of them severe) in the 25 patients was predicted by a positive result from the skin or conjunctival test. The two patients in whom positive results were yielded from the tests did not have reactions. Five patients developed late serum sickness type reactions five to 
TABLE II--Comparison of intravenous injection and infusion of antivenom in 66 Thai patients bitten by snakes

\begin{tabular}{|c|c|c|c|c|c|c|c|c|c|c|}
\hline \multirow[b]{2}{*}{$\begin{array}{l}\text { Biting species of } \\
\text { snake }\end{array}$} & \multirow[b]{2}{*}{$\begin{array}{c}\text { Severity of } \\
\text { envenoming } \\
\text { (No of patients) }\end{array}$} & \multicolumn{3}{|c|}{ Antivenom } & \multicolumn{3}{|c|}{ Infusion } & \multicolumn{3}{|c|}{ Injection } \\
\hline & & Manufacturer & Specificity & $\begin{array}{c}\text { Dose } \\
\text { (ampoules) }\end{array}$ & $\begin{array}{c}\text { No of } \\
\text { patients }\end{array}$ & $\begin{array}{l}\text { No of } \\
\text { reactions }\end{array}$ & $\begin{array}{l}\text { No of } \\
\text { severe } \\
\text { reactions }\end{array}$ & $\begin{array}{c}\text { No of } \\
\text { patients }\end{array}$ & $\begin{array}{c}\text { No of } \\
\text { reactions }\end{array}$ & $\begin{array}{l}\text { No of } \\
\text { severe } \\
\text { reactions }\end{array}$ \\
\hline $\begin{array}{l}\text { Trimeresurus albolabris } \\
\text { T macrops }\end{array}$ & $\left\{\begin{array}{l}\text { Local (12) } \\
\text { Systemic (3) }\end{array}\right.$ & TRC & Green pit viper & 1 & 8 & 3 & 0 & 7 & 2 & 6 \\
\hline Talbolabris & Systemic & TRC & Green pit viper & 5 & 2 & 1 & 0 & 3 & 2 & 1 \\
\hline Calloselasma rhodostoma & Systemic & TRC, TGPO, Twyford & Malayan pit viper & 5 & 23 & 14 & 5 & 23 & 10 & 4 \\
\hline Total & & & & & 33 & $18^{\star}$ & $5 t$ & 33 & $14^{\star}$ & $6+$ \\
\hline
\end{tabular}

TRC $=$ Queen Saovabha Memorial Institute (Thai Red Cross Society), Bangkok; TGPO=Thai Government Pharmaceutical Organisation, Bangkok; Twyford = Twyford Pharmaceuticals GmbH, Ludwigshafen

${ }^{\star} \chi^{2}=0 \cdot 97, \mathrm{p}>0.3 .+\chi^{2}=0.97, \mathrm{p}>0 \cdot 3$.

TABLE III-Details of 28 Thai patients bitten by snakes included in immunological studies of early reactions to antivenom

\begin{tabular}{|c|c|c|c|c|c|c|c|c|c|c|c|}
\hline \multirow[b]{2}{*}{$\begin{array}{l}\text { Biting species of } \\
\text { snake }\end{array}$} & \multirow[b]{2}{*}{$\begin{array}{c}\text { Severity of } \\
\text { envenoming } \\
\text { (No of patients) }\end{array}$} & \multicolumn{3}{|c|}{ Thai Red Cross antivenom } & \multirow[b]{2}{*}{$\begin{array}{c}\text { Total } \\
\text { No of } \\
\text { patients }\end{array}$} & \multicolumn{2}{|c|}{$\begin{array}{l}\text { Negative results from } \\
\text { skin tests }\end{array}$} & \multicolumn{2}{|c|}{$\begin{array}{l}\text { Positive results from } \\
\text { skin tests }\end{array}$} & \multicolumn{2}{|c|}{ Skin test not done } \\
\hline & & Specificity & $\begin{array}{c}\text { Dose } \\
\text { (ampoules) }\end{array}$ & $\begin{array}{c}\text { Method } \\
\text { of } \\
\text { administration }\end{array}$ & & $\begin{array}{c}\text { No of } \\
\text { patients }\end{array}$ & $\begin{array}{l}\text { No of } \\
\text { reactions } \\
\text { (severe) }\end{array}$ & $\begin{array}{c}\text { No of } \\
\text { patients }\end{array}$ & $\begin{array}{l}\text { No of } \\
\text { reactions }\end{array}$ & $\begin{array}{c}\text { No of } \\
\text { patients }\end{array}$ & $\begin{array}{l}\text { No of } \\
\text { reactions } \\
\text { (severe) }\end{array}$ \\
\hline Trimeresurus albolabris & Local (12) & & & Infusion & 8 & 8 & 3 & 0 & 0 & - & $3(0)$ \\
\hline T macrops & Systemic (3) & Green pit viper & 1 & Injection & 7 & 6 & $2(1)$ & 1 & 0 & - & - \\
\hline Calloselasma rhodostoma & Systemic & Malayan pit viper & 5 & Infusion & 11 & 4 & $2(2)$ & 0 & 0 & 7 & $3(0)$ \\
\hline Naja kaouthia & Local & Cobra & 5 & Infusion & 2 & 1 & $1(0)$ & - & - & 1 & 0 \\
\hline Total & & & & & 28 & 19 & $8(3)$ & 1 & 0 & 8 & $6(0)$ \\
\hline
\end{tabular}

TABLE IV-Immunological results in 26 healthy Thai controls and 28 patients bitten by snakes

\begin{tabular}{|c|c|c|c|c|c|}
\hline \multirow[b]{2}{*}{ Assay } & \multicolumn{2}{|c|}{ Controls } & \multicolumn{3}{|c|}{ Snake bitten patients } \\
\hline & No of samples & Mean $(2 S D) \%^{\star}$ & No of samples & Mean (2 SD & $\% \star$ \\
\hline \multicolumn{6}{|c|}{ Complement components: } \\
\hline $\mathrm{C} 3$ & 25 & $124 \cdot 1(60 \cdot 4)$ & 103 & $97 \cdot 2(50$ & \\
\hline $\mathrm{C} 4$ & 26 & $112.4(93.6)$ & 103 & $91 \cdot 3(80$ & \\
\hline $\mathrm{C} 3 \mathrm{~b}$ & 26 & 0 & 103 & 0 & \\
\hline \multirow[t]{2}{*}{ C3d } & 26 & 0 & 103 & 0 & \\
\hline & & an (2 SD) \% binding & & $\begin{array}{l}\text { No of positive results } \\
\quad(\text { mean }(2 \text { SD }))\end{array}$ & $\begin{array}{c}\text { No of } \\
\text { negative results }\end{array}$ \\
\hline \multicolumn{6}{|c|}{ Immune complex assays: } \\
\hline Protein $\mathrm{A}$ binding & 19 & $2 \cdot 25(2 \cdot 06)$ & 229 & $10(5 \cdot 8(2 \cdot 0))$ & 219 \\
\hline $\mathrm{Clq}$ binding & 20 & $1.56(1.34)$ & 237 & $34(6.8(5.0))$ & 203 \\
\hline Conglutinin & 20 & $2 \cdot 76(1.49)$ & 104 & $17(13 \cdot 7(19 \cdot 8))$ & 87 \\
\hline
\end{tabular}

* \% Of a pool of 120 plasma samples from healthy Thai subjects.

17 days after receiving total doses of $10-200 \mathrm{ml}$ of antivenom. In none of these patients were positive results yielded from skin tests. Follow up was not adequate for an assessment of the incidence of late reactions.

\section{COMPARISON OF INTRAVENOUS INJECTION AND INFUSION OF ANTIVENOM}

There was no significant difference in the incidence or severity of early reactions between the group of 33 patients given diluted antivenom by infusion and the other group of 33 given undiluted antivenom by intravenous injection (table II).

\section{IMMUNOLOGICAL STUDIES}

Table III gives the details of the 28 Thai patients included in the immunological studies of early reactions to antivenom. Eleven of these 28 patients had early reactions. Plasma samples obtained before the skin test was performed and five and 30 minutes after the start of intravenous antivenom treatment were assayed blind for complement components and breakdown products. All the results were within the range (mean (SD)) of a group of healthy subjects (see table IV). All samples from the 11 patients who reacted to antivenom were then assayed, including those taken at the first sign of the reaction. Results from these assays were also within the normal range. Pooled results from all 103 samples that were analysed, for both $\mathrm{C} 3$ and $\mathrm{C} 4$, did not differ significantly from the 26 control samples (table IV). C3b and C3d were not detected in any of the samples from patients or controls.

Most of the serum samples were assayed blind for immune complexes with protein $\mathrm{A}$ and $\mathrm{Clq}$ binding assays. Samples from the 11 reactive Thai patients were also tested by the conglutinin binding assay. Immune complexes were detected by one or more assays in six patients, but in all cases they were present in samples taken before skin tests were performed and after treatment. There was no consistent change in binding activity after antivenom treatment and no association between the presence of complexes and the development of an early reaction.

\section{ASSESSMENT OF IN VITRO COMPLEMENT ACTIVATION BY ANTIVENOM}

In vitro testing showed dose dependent antivenom activation of complement by both classical and alternative pathways. Removal of aggregates by centrifugation reduced this activation. The smallest ratio of the amount of antivenom to normal serum giving significant $C 3$ conversion was $1: 6 \cdot 3$. This would be equivalent to giving $400 \mathrm{ml}$ of antivenom to a person with a blood volume of 51 . 


\section{Discussion}

Many authorities on snake bites have recommended the use of sensitivity testing but at the same time provided evidence of its unreliability ${ }^{1418-20} 2930$ and even potential lethality. ${ }^{20}$ Others have considered this test to be useless. ${ }^{381521}$ Neither opinion has been backed up by prospective data. Results of our sensitivity tests in 25 Nigerian and Thai patients prove that these conventional tests have no predictive value for the occurrence of early reactions, even severe system anaphylaxis. It is not justifiable to delay antivenom treatment for 20 or 30 minutes to read the results of sensitivity tests. As early reactions are common, unpredictable, and occasionally life threatening all patients treated with antivenom must be regarded as potentially reactive. We were unable to study late serum sickness type reactions, but published reports provide no convincing evidence that they are predicted by the results of sensitivity tests.

Most authorities recommend that antivenom should be diluted in $200-500 \mathrm{ml}^{2022}$ or more of isotonic fluid and given by slow intravenous infusion. The rate of administration can be more easily controlled by this method, but it has serious disadvantages in the rural tropics where most cases of snake bite occur. Intravenous fluids and administration sets are expensive, they take longer to set up, and the fluid may run in precipitously unless supervised. In this study the slow infusion of diluted antivenom given to 33 patients did not decrease the incidence or severity of early reactions. An advantage of the intravenous "push" injection given over 10 minutes is that the person giving the injection must remain with the patient during the period when most severe anaphylactic reactions develop. By increasing the dilution of antivenom and prolonging its infusion we might have produced a different result, but the danger of overloading with fluid, especially in children, and the urgent need to neutralise circulating venom precludes these methods.

Reactions to homologous immunoglobulin resemble reactions to antivenom in that they are not predicted by the results of skin tests. ${ }^{31}$ Severe vasomotor symptoms are commoner after homologous serum has been given, ${ }^{32}{ }^{33}$ but urticaria, the commonest manifestation of antivenom reactions, is rarely mentioned in accounts of these reactions. The differences may be explained by the fact that at least 10 times more human than equine protein is administered $(200 \mathrm{mg}$ human protein $/ \mathrm{kg}$ body weight, or $10 \mathrm{~g}$ of human protein for a patient weighing $50 \mathrm{~kg}$ compared with $1-5 \mathrm{~g}$ of equine protein for the same patient).

There is convincing evidence that early reactions to homologous serum and late serum sickness type reactions to antivenom are related to complement activation by immune complexes (aggregates)..$^{32}{ }^{34}$ Complement activation and immune complexes were detected after infusion of human immunoglobulin, even in those patients who remained asymptomatic. In accord with Sutherland, ${ }^{21}$ we found that the Thai Red Cross antivenom activated complement in vitro. Fairly large amounts of antivenom were required, however, and in vivo there was no evidence of complement activation or the appearance of immune complexes after antivenom treatment, even in the 11 patients who had overt reactions (three of them had severe generalised anaphylaxis). Complement activation was unlikely to have been missed as we used sensitive assays and took frequent samples.

Hypogammaglobulinaemic patients appear more susceptible to homologous serum reactions than others, and Soothill suggested that the patients' ability to filter out aggregates may determine whether they develop a reaction. ${ }^{31}$ If the removal of circulating IgG aggregates by the reticuloendothelial system was more efficient in our healthy patients bitten by snakes given equine serum than in immunosuppressed and hypogammaglobulinaemic patients given homologous serum the differences in severity of reactions and detection of immune complexes would be partly explained.

Several snake venoms are known to activate complement by the classical or alternative pathway, ${ }^{34}$ and reduced concentrations of complement components and complement breakdown products have been detected in serum samples from envenomed patients..$^{35}$ These changes were not detected before antivenom treatment in the patients studied in Thailand, probably because many of them were mildly envenomed.
Fatal anaphylaxis is the main hazard of antivenom treatment. Rare disasters have led to the wholesale rejection of antivenom treatment. ${ }^{1213}$ Further studies are needed to discover the mechanism of early reactions. The idea of complement activation, already shown in patients given large doses of homologous serum, is attractive but has not yet been shown convincingly in victims of snake bites.

We thank our many clinical and nursing colleagues at the various hospitals for their help; Dr B M Greenwood, Dr May Ho, and Professor Peter Lachmann for valuable advice; Mrs Helen Watkins, Mrs Kamolrat Silamut, Mrs Vanaporn Wuthiekanun, and Khun Sa-Nga Patanakitsakul for excellent technical help; Ms Kristin Headlam and Miss Eunice Berry for typing; and Professor E H O Parry, Professor Khunying Tranakchit Harinasuta, and Professor Danai Bunnag for their help and encouragement. This study was part of the Wellcome-Mahidol University Oxford Tropical Medicine Research Programme funded by the Wellcome Trust.

\section{References}

1 Martin CJ. Further observations concerning the relation of the toxin and antitoxin of snake venom. Proc $R$ Soc Lond 1898;64:88-94.

2 Christensen PA. The treatment of snake bite. S Afr Med f 1969;43:1253-8.

3 Anonymous. Antivenom therapy and reactions [editorial]. Lancet 1980;i:1009-10.

4 Corrigan P, Russell FE, Wainschel J. Clinical reactions to antivenin. Toxicon 1978;16(suppl 1): 457-65.

5 Trinca FG. The treatment of snake bite. Med f Aust 1963;i:275-80.

6 Sutherland SK, Lovering KE. Antivenoms. Use and adverse reactions over a 12 -month period in Australia and Papua New Guinea. Med J Aust 1979;ii:671-4.

7 Warrell DA. Clinical snake bite problems in the Nigerian savanna region. Technische Hochschule Darmstadt, Schriftenreihe Wissenschaft u-Technik 1979;14:31-60.

Darmstadt, Schnftenrethe Wissenschaft $u$-Technik 1979;14:31-60.
Reid HA. Antivenom reactions and efficacy. Lancet 1980;i:1024-5.

8 Reid HA. Antivenom reactions and efficacy. Lancet 1980;i:1024-5. Christensen PA. Snakebite and the use of antivenom in sout
934-8.

0 Reid HA. Adder bites in Britain. Br Med F 1976;ii:153-6.

11 Kojis FG. Serum sickness and anaphylaxis. Am J Dis Child 1942;64:93-143.

12 Royal Society of Tropical Medicine and Hygiene. Notes on the treatment of snakebite. Trans $R$ Soc Trop Med Hyg 1962;56:93-4.

13 British Medical Association and The Pharmaceutical Society of Great Britain. British National Formulary. London: British Medical Association and The Pharmaceutical Society of Great Britain, 1981; No 2:24.

14 Parrish HM, Hayes RH. Hospital management of pit viper venenation. In: Minton SA, ed. Snake venoms and envenomation. New York: Marcel Dekker, 1971:155-65.

15 World Health Organisation. Progress in the characterisation of venoms and standardisation of antivenoms. Geneva: WHO, 1981. (WHO Offset Publications, No 58.)

16 Laurent LJM, Parish HJ. Serum reactions and serum sensitivity tests. Br Med f 1952;ii:1294-7.

17 Black RE, Gunn RA. Hypersensitivity reactions associated with botulinal antitoxin. Am $\mathcal{F}$ Med 1980;69:561-70.

18 McCollough NC, Gennaro JF. Treatment of venomous snake-bite in the United States. In Minton SA, ed. Snake venoms and envenomation. New York: Marcel Dekker, 1971:137-54.

19 Wingert WA, Wainschel J. Diagnosis and management of envenomation by poisonous snakes. South Med f 1975;68:1015-26.

20 Russell FE. Snake venom poisoning. Philadelphia: Lippincott, 1980.

21 Sutherland SK. Serum reactions: an analysis of commercial antivenoms and the possible role of anticomplementary activity in de novo reactions to antivenoms and antitoxins. Med $\mathcal{J}$ Aust 1977;i:613-5.

22 Reid HA. Snakebite. Part 2: treatment. Trop Doct 1972;ii:159-63.

23 Stevens WJ, Bridts C. A method for rapid determination of IgG containing circulating immune complexes using polyethylene glycol and radioactively labelled protein A. Immunological Letters 1981;3:44.

24 Zubler RH, Lange G, Lambert PH, Meischer PA. Detection of immune complexes in unheated sera by a modified ${ }^{125}$ I-Clq binding test. $f$ Immunol 1976;116:232-5.

25 Casali P, Bossus A, Carpentier NA, Lambert PH. Solid-phase enzyme immunoassay or radioimmunoassay for the detection of immune complexes based on their recognition by conglutinin: conglutinin-binding test. Clin Exp Immunol 1977;29:342-54.

26 Fraker PJ, Speck JC. Protein and cell membrane iodination with sparingly soluble chloramide, 1 3, 4, 6-tetra-chloro-3a, 6a diphenyl glycolutil. Biochem Biophys Res Commun 1978;80:849.

27 Thompson RA. Techniques in clinical immunology. Oxford: Blackwell, 1981:91.

28 Branslund I, Siersted HE, Svehag SE, Teisner B. Double-decker rocket immunoelectrophoresis for direct quantitation of complement $\mathrm{C} 3$ split products with C3d specificities in plasma. $\mathcal{J}$ Immunol Methods 1981;44:63-71.

29 Rosenfeld G. Symptomatology, pathology and treatment of snake bites in South America. In Bucherl W, Buckley EE, eds. Venomous animals and their venoms. New York: Academic Press, 1971:345-84.

30 Russell FE, Timmerman WF, Meadows PE. Clinical use of antivenin prepared from goat serum. Toxicon 1970;8:63-5.

31 Soothill JF. Reactions to immunoglobulins. Hypogammaglobulinaemia in the United Kingdom. London: Medical Research Council, 1971. (MRC Special Reports Series No 310.)

32 Day NK, Good RA, Wahn V. Adverse reactions in selected patients following intravenous infusion of gammaglobulin. Am $\mathcal{J}$ Med 1984;76:25-32.

33 Pirofsky B. Intravenous immune globulin therapy in hypogammaglobulinaemia. Am $7 \mathrm{Med}$ 1984; 76:53-60

34 Birdsey V, Lindorfer J, Gewurz H. Interaction of toxic venoms with the complement system. Immunology 1971;21:299-310.

35 Nielsen H, Sørensen H, Faber V, Svehag SE. Circulating immune complexes, complemen activation kinetics and serum sickness following treatment with heterologous anti-snake venom globulin. Scand I Immunol 1978;7:24-33.

(Accepted 15 October 1985) 